REVIEW

\title{
Reporting of gunshot wounds by doctors in emergency departments: A duty or a right? Some legal and ethical issues surrounding breaking patient confidentiality
}

\section{A Frampton}

Emerg Med J 2005;22:84-86. doi: 10.1136/emj.2004.016733

Recent guidelines have been produced advising doctors working in emergency departments that they should report all gunshot injuries to the police (albeit with consent in all but very limited circumstances). This article will discuss some of the legal and ethical issues that surround breaking patient confidentiality in relation to gunshot wounds and other potentially dangerous patients; and looks at some cases from the UK and the USA where such issues have been ruled on. Finally, the issue of whether physicians do, or should, have a duty to warn when they feel that their patient may be dangerous will be discussed.

Correspondence to: Dr A Frampton, Emergency Department, Southampton General Hospital, Tremona Road, Southampton SO16 6YD UK; anneframpton2003@ yahoo.co.uk

Accepted for publication 6 June 2004
I n 2003 the General Medical Council (GMC) produced guidelines advising doctors working in emergency departments that they should report all gunshot injuries to the police. The guidelines (appendix 1, available on line http:// www.emjonline.com/supplemental) include that patient details should not be disclosed without prior consent of the patient unless certain specific circumstances apply. However, it is easy tity might unwittingly be disclosed without their consent. The singling out of this patient group raises some legitimate ethical and legal concerns. It potentially also opens the door for imposing a duty on physicians, who believe a patient to be potentially dangerous, to warn; the consequences of this may be significant. This article will attempt to discuss some of these issues.

\section{GUNSHOT WOUNDS}

The incidence of gunshot wounds is rising in the UK. There were 9974 incidents involving firearms in the year to April 2002 (Home Office figures), about $50 \%$ occurring in London. The number of men murdered by shooting in the year to April 2002 also increased by $41 \%$ when compared with the previous 12 months.

While the guidelines are clear regarding the current position on breaking confidentiality to release patient details, it is easy to imagine a situation in a busy emergency department where the arrival of the police could lead to a member of the emergency department staff either unwittingly revealing the patient's name, or where the identity of the patient is revealed by simply looking at an information board in the department. to imagine a situation where the patient's iden-
Does gun crime, above all other forms of violent crime, justify this potential loss of confidentiality? And do we believe as Emson ${ }^{1}$ controversially states; "Society's acquiescence to the erosion of confidentiality by statutory requirements for reporting can be assumed because there has been no general public opposition to their extension".

\section{A DUTY OF CONFIDENTIALITY?}

Whatever, in connection with my professional practice, or not in connection with it, I see or hear in the life of men, which ought not to be spoken of abroad, I will not divulge, as reckoning that all such should be kept secret. (The Hippocratic oath)

That a doctor owes a duty of confidentiality to his patients has long been accepted, although this duty until recently has been based in ethics and case law, rather than upheld by statute. Kennedy and Grubb ${ }^{2}$ have described the duty as "one of the most fundamental ethical obligations owed by a doctor to his patient" and Warwick $^{3}$ has suggested that one reason for supporting the duty of medical confidentiality has been respect for medical codes. However, even those who believe that the Hippocratic oath still has relevance to medical practice today should note that the oath considers that which "ought not" to be spread abroad. Presumably this caveat allowed for some circumstances, apparently undefined, where a physician may breach confidence if he felt it necessary.

The courts have also made it clear that they too expect a duty of confidentiality, save in a few exceptional circumstances. In $W \quad v \quad$ Egdell, ${ }^{4}$ Bingham LJ stated "It has never been doubted that the circumstances were such as to impose on Dr Egdell a duty of confidence owed to $\mathrm{W}^{\prime \prime}$ and in their guidelines to practitioners, the GMC have stated that "patients have a right to expect that information about them will be held in confidence by their doctors. Confidentiality is central to trust between doctors and patients." ${ }^{5}$ The coming into force of Article 8 of the European Convention on Human Rights stating that "everyone has a right to respect for his private life, his home and his correspondence" may add some statutory weight to the obligation of confidentiality. 


\section{A RELATIVE OR AN ABSOLUTE DUTY OF CONFIDENCE?}

I will respect the secrets which are confided in me, even after the patient has died. Declaration of Geneva (as amended Sydney 1968)

Having established that a duty of confidence exists, it is necessary to consider whether this duty is absolute or relative. Kottow ${ }^{6}$ takes the view that "breaching confidentiality causes harms that are not commensurate with the possible benefits gained." He continues that "excusing breaches of confidence on the grounds of superior moral values introduces arbitrariness and ethical unreliability into the medical context". Much of Kottow's argument is based around the notion that if doctors are thought of as confidence breakers then others will not seek the necessary help. This concern was also considered by Rose $\mathrm{J}$ in $X v Y^{7}$, a case related to disclosure of identity of patients with HIV; "If people felt that there was any chance of information given to their doctor, or the doctor's diagnosis being passed on, people would be reluctant to seek advice and the disease would go underground. Confidentiality must be absolute or almost absolute". In relation to gun crime, if those who, for whatever reason, do not what their identities disclosed believe that their confidentiality will be breached by attending an emergency department, they may be reluctant to seek essential medical help. Kottow goes further suggesting that not only is it unfair to extract information from patients and then disclose it, he also suggests that those who disclose should be prepared to take whatever consequences may result, be it blackmail or threats to the person.

Kottow's somewhat extreme position fails to consider the wider picture. Doctors are members of the society in which they live, not isolated individuals and as such also have some responsibility to that society. Knowingly allowing someone to continue to commit, for example, violent crimes it could be argued is just as morally wrong as informing the relevant authorities about a patient. A doctor who fails to warn of a violent patient who carries on offending must live with the consequences of his actions both personally and within his community; if his inaction comes to light at a later stage it is likely that he will suffer severe criticism, if not from the law, from the general public. Indeed in the long run it may even be possible that maintaining the confidentiality of an extremely dangerous patient will eventually harm the doctor's relationships with his other patients if discovered.

\section{THE PUBLIC INTEREST}

One exception to confidentiality frequently cited is when it is in "the public interest", indeed GMC guidelines on the subject state "exceptionally, in cases where patients withhold consent, personal information may be disclosed in the public interest where the benefits to an individual or to society outweigh the public and patients interest in keeping the information confidential..."

This guideline considers the public interest in terms of maintaining confidentiality as well as breeching it. As mentioned already, any disclosure contrary to the private interest may also be potentially damaging to the public interest because it inhibits open disclosure to medical practitioners. ${ }^{8}$ There are several examples from the courts where just this position has been considered. ' In $X v Y$, Justice Rose stated "in the long run, preservation of confidentiality is the only way of securing public health." In another judgment the House of Lords upheld the NSPCC's right not to reveal the name of an informant who had provided information indicating possible child abuse. ${ }^{10}$ They held that people with such information should be able to volunteer it freely and have their confidence maintained without fear of legal action. On the one hand therefore this judgment seemed to honour the notion of confidentiality, but suppose the informant was a doctor who had received the information in confidence; perhaps this would counter the argument by Kottow that those who break confidentiality deserve to suffer the consequences?

The case of $W v$ Egdell gives an insight into how the courts may view a breech of confidentiality "in the public interest". Dr Egdell prepared a psychiatric report on behalf of W who was applying for transfer to a less secure unit, having been detained initially after killing five people. He strongly opposed the transfer having formed the view that $\mathrm{W}$ continued to represent a serious danger and expressed concern at the possibility of release or transfer. On receiving the report W's solicitors withdrew the application to the tribunal. On learning that his report would not therefore be viewed Dr Egdell sent his report to the hospital director and the home secretary.

In the High Court, Justice Scott held that the duty of confidence owed to the patient was subordinate to the public interest in ensuring that there was a proper assessment of W's mental condition. On appeal Bingham LJ stated;

The decided cases very clearly establish: 1) that the law recognises an important public interest in maintaining professional duties of confidence; but 2) that the law treats such duties not as absolute but as liable to be overridden where there is held to be a stronger public interest in disclosure.

\section{A DUTY TO DISCLOSE?}

The law requires disclosure of information under certain circumstances governed by statute, for example, the notification of certain infectious diseases and disclosure relating to offences under the Road Traffic Act of 1972. The case of Hunter $v$ Mann ${ }^{11}$ confirmed that the courts do not regard patient confidentiality a defence to the non-disclosure of information in these circumstances. The statutory duty of disclosure in these cases could be regarded as removing some of the moral dilemmas that doctors may face. Others may argue that just because something is law does not make it morally right. McConnell ${ }^{12}$ argues that physicians are not warranted in breaching confidentiality because they are required by law to do so. Like Kottow he is concerned that information gained in this way could be used for other purposes. Veatch on the other hand takes the opposite standpoint;

The physician is after all, a citizen of the land and subject to the laws of the land. To decide to break the law, even when it appears justified even by a professional code of ethics with a principle as established as that of confidentiality, is no trivial decision; it is civil disobedience. ${ }^{13}$

McConnell objects however to the suggestion that his position denies that each citizen has an obligation to obey duly enacted laws. Instead he claims that in certain circumstances where the duty to the patient and the duty to the law conflict, the law should not always be more important than the duty of confidentiality. In reality however it is probable that most physicians are likely to adhere to the law in situations governed by statute. Concerns such as those expressed by Kottow and McConnell regarding for example legislation to require the identification of those with HIV have shown no signs of becoming a reality at least in the UK courts; indeed with regard to this particular disease the courts seem to have set a clear precedent for maintaining the confidentiality of these patients as far as possible. When considering these concerns it should also be remembered that the law requires only the minimum amount of data required for identification purposes, other personal or medical information should remain confidential. Boreham J in Hunter V Mann stated "he [the medical 
practitioner] only has to disclose information which may lead to identification and not other confidential matters."

What about a duty to disclose information not governed by statute such as threats from a potentially violent patient, a gunshot injury, or a man who refuses to tell his wife that he is HIV positive. From the discussion above it is likely that a doctor could justifiably disclose such information as long as it was in the "public interest" but does that make him liable for harm that may occur if he chooses to maintain confidentiality?

The implementation of the Human Rights Act into UK law raises this possibility. There is no duty to rescue under UK law and even as recently as 1997 courts have confirmed that a doctor has no obligation to aid in a road traffic accident that he witnesses. Article 2 of the Human Rights Act however implies a positive obligation on authorities to take preventative operational measures to protect a person whose life is at risk from the criminal acts of another person.

The key, as far as rulings in the UK are concerned at present, seem to be that a duty arises only when the victim is identifiable and there is a risk to life. Palmer $v$ Tees HA shows the requirement by the courts that the person be identifiable. ${ }^{14}$ In 1994, Rosie Palmer, the claimant's daughter was abducted and murdered by Armstrong, a man who had previously been under the care of Hartlepool General Hospital for a psychiatric disorder. It was alleged that the defendant failed to diagnose the serious risk that Armstrong posed to children, and failed to take any action to prevent him committing this crime. The appeal was dismissed however holding that the health authority did not owe Rosie Palmer a duty of care because she was an unidentifiable victim. At the initial trial Gage J stated;

In cases where it is alleged that a defendant by his negligence is responsible for the actions of a third party it must be shown that the victim or injured person was one who came into a special or exceptional or distinctive category of risk from the activities of the third party. It is not sufficient to show that the victim or injured party was one of the wide category members of the general public.

The position in the US on this matter has evolved over the past 30 years and has developed further however. The original case $^{15}$ in the 1970s concerned a student, Poddar, who became obsessed with a fellow student Tatiana Tarasoff. After a brief affair she ended the relationship. Poddar became increasingly obsessed with Tarasoff and sought help from the university counselling service. He confessed to the psychotherapist that he was considering killing Tarasoff and the therapist became so concerned that he alerted the campus police who arrested Poddar. Having convinced the police that his threats were not serious he was released and stopped his counselling sessions. Two months later he murdered Tarasoff. The court found that the psychotherapist had failed in his duty to warn a clearly identifiable victim holding that "when a doctor ... in the exercise of his professional skill and knowledge... determines, or should determine, that warning is essential to avert danger arising from the medical or psychological condition of his patient, he incurs a legal obligation to give that warning". A second opinion went even further transforming the duty to warn to a duty to protect. Before the implementation of Article 2 of the Human Rights Act it was said that "the courts in this country (UK) would be unlikely within the present scope of the tort of negligence to extend liability to the Tarasoff type case."16 The court in Palmer vs Tees considered the Tarasoff verdict and concluded that as with the Tarasoff case the victim must be readily identifiable. However, since Tarasoff, US courts have gone further, foregoing the requirement of any identifiable victim. The Tarasoff verdict in theory may also allow a doctor to be sued for negligence for not only failing to warn an identifiable victim, but also for failing to determine that his patient posed a risk.

Perhaps a more probable scenario where a doctor my be held liable for death or injury to an unidentified victim relates to the law and driving. In Canada, a physician was held liable for failing to report a person with epilepsy as a potentially dangerous driver and judged guilty of negligence when the patient was involved in an accident. ${ }^{17}$ The danger was to society in general not a specific potential victim, but in this case the court held that there was a statutory duty and its breach was the basis for civil negligence. No such statutory duty exists in the UK although a doctor who fails to advise a patient that they should not drive may be held liable. GMC guidance allows a doctor to report a patient who is unfit to drive to the DVLA once they have made a concerted effort to persuade the patient to disclose the information himself. If a doctor failed to disclose the information having made these efforts it is difficult to say whether a court would ever consider that he should have breeched the confidence of the patient to disclose the information.

\section{CONCLUSION}

Gun crime is an increasing problem in society; as members of that society doctors are no different from others in their duty to uphold the law and behave in a moral and ethical manner. In some situations the doctor's duty of confidentiality to his patient will have to be weighed against his legal and moral obligations to that society.

That doctors should be allowed to disclose information, even without consent, on patients who they believe are a danger to the public is supported by GMC guidelines and common law. Whether they have a duty in law to warn in the UK is less clear. A review of the Human Rights Act would suggest not, unless the future victims are identifiable. A duty to warn brings with it a duty of care imposing what for many would be an undesirable burden leaving the way open for negligence litigation when a patient commits a crime the victim feels may have been predictable. Few doctors would relish being held accountable for their patients' crimes, and few patients would relish the effective power it would give to medical practitioners.

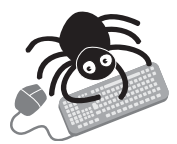

The appendix is available on line (http://www. emionline.com/supplemental).

Funding: none.

Conflicts of interest: none declared.

\section{REFERENCES}

1 Emson HE. Confidentiality: a modified value. J Med Ethics 1988;14:87-90.

2 Kennedy and Grubb. Medical law. 3rd ed. London: Butterworths, 2000.

3 Warwick SJ. A vote for no confidence. J Med Ethics 1989;15:183-5.

4 W v Egdell [1990] 1 All ER 359

5 General Medical Council. Confidentiality: protecting and providing information. London: GMC, section 1, 1.

6 Kottow MH. Medical confidentiality: an intransient and absolute obligation. $J$ Med Ethics 1986;12:117-22.

$7 \mathrm{X} v \mathrm{Y}$ [1988] 2 All ER 477

8 Lee R. Confidentiality and medical records. In: Dyer C. Doctors, patients and the law. Oxford: Blackwell Scientific, 1992.

$9 \mathrm{H}$ (a healthcare worker) v Associated Newspapers Ltd [2002] EMLR 23.

10 D v NSPCC [1978] AC 171

11 Hunter $\vee$ Mann [1974] DC.

12 McConnell T. Confidentiality and the law. J Med Ethics 1994;20:47-9.

13 Veatch R. Case studies in medical ethics. Cambridge MA: Harvard University Press, 1977:117.

14 Palmer v Tees HA [2000] PIQR 1

15 Tarasoff $v$ Regents of the University of California 551 P 2d 334 9Cal 1976.

16 Mackay R. Dangerous patients. Third party safety and psychiatrists dutieswalking the Tarasoff tightrope. Med Sci Law 1990;30:56.

17 Ottawa Citizen Jan 14;1993:A6. 